УДК 657.1.339.7

Кулинич Мирослава, кандидат економічних наук, доцент, Волинський національний університет імені Лесі Українки, кафедра обліку і аудиту, м. Луцьк; ORCID ID 0000-0001-9024-2924 e-mail:kulmiros@gmail.com

https://doi.org/10.29038/2411-4014-2020-04-97-103

\title{
УДОСКОНАЛЕННЯ ЕЛЕМЕНТІВ МЕТОДУ БУХГАЛТЕРСЬКОГО ОБЛІКУ В КОНТЕКСТІ ЦИФРОВОЇ МОДЕРНІЗАЦІЇ ЕКОНОМІКИ
}

\begin{abstract}
Швидкий розвиток цифрової економіки як у всьому світі так і в нашій країні, впливає на всі сфери діяльності, в тому числі і на облікові процеси. Бухгалтерський облік у теоретичному і в практичному плані, також зазнає істотних змін. Проте методологія та інструментарій бухгалтерського обліку не завжди відповідають сучасним реаліям, в силу чого виникає ряд проблем, повязаних 3 впровадженням цифрових рішень. На підприємствах автоматизується збір і реєстрація первинної інформації з використанням сучасних засобів вимірювання, що забезпечує документування господарських операцій винятково в електронній формі. Удосконалення теорії і формування практики ведення бухгалтерського обліку теоретично об'єднані 3 розширенням інформаційного потенціалу наявного економічного простору. В статті розглядається розширення відображення області діяльності організації в обліку; підвищення якості інформації та оперативності обліку, виявлення і збільшення числа нових об'єктів обліку, розробка інноваційних методів оцінки нових об'єктів обліку, формування підходів до інтегрування різних видів обліку, використання сучасних інформаційних технологій збору i опрацювання інформації (блокчейн-технології), розробка теоретичних, методичних і прикладних аспектів розвитку бухгалтерського обліку.
\end{abstract}

Ключові слова: облік, цифровізація, документація, інвентаризація, оцінка, електронна звітність, вартість.

Кулинич Мирослава, кандидат экономических наук, доцент, Волынский национальный университет имени Леси Украинки, кафедра учета и налогообложения, г. Луцк

\section{УСОВЕРШЕНСТВОВАНИЕ ЭЛЕМЕНТОВ МЕТОДА БУХГАЛТЕРСКОГО УЧЕТА В КОНТЕКСТЕ ЦИФРОВОЙ МОДЕРНИЗАЦИИ ЭКОНОМИКИ}

Быстрое развитие цифровой экономики как во всем мире так и в нашей стране, влияет на все сферы деятельности, в том числе и на учетные процессы. Бухгалтерский учет в теоретическом и в практическом плане, также претерпевает существенные изменения. Однако методология и инструментарий бухгалтерского учета не всегда соответствуют современным реалиям, в силу чего возникает ряд проблем, связанных с внедрением цифровых решений. На предприятиях автоматизируется сбор и регистрация первичной информации с использованием современных средств измерения, обеспечивает документирование хозяйственных операций исключительно в электронной форме. Совершенствование теории и формирование практики ведения бухгалтерского учета теоретически объединены с расширением информационного потенциала имеющегося экономического пространства. В статье рассматривается расширение отображения области деятельности организации в учете; повышение качества информации и оперативности учета, выявление и увеличение числа новых объектов учета, разработка инновационных методов оценки новых объектов учета, формирования подходов к интегрированию различных видов учета, использования современных информационных технологий сбора и обработки информации (блокчейн-технологии), разработка теоретических, методических и прикладных аспектов развития бухгалтерского учета.

Ключевые слова: учет, цифровизация, документация, инвентаризация, оценка, электронная отчетность, стоимость. 


\section{Kulynych Myroslava, PhD in Economics, Associate Professor, Lesya Ukrainka Volyn National University, Department of Accounting and Auditing, Lutsk}

\section{IMPROVEMENT OF ACCOUNTING ELEMENTS IN THE CONTEXT OF DIGITAL MODERNIZATION OF THE ECONOMY}

The rapid development of the digital economy, both worldwide and in our country, affects all areas of activity, including accounting processes. Accounting in theoretical and practical terms, is also undergoing significant changes. However, the methodology and tools of accounting do not always correspond to modern realities, due to which there are a number of problems associated with the implementation of digital solutions. The enterprises automate the collection and registration of primary information using modern measuring instruments, which provides documentation of business transactions exclusively in electronic form. Improvements in the theory and formation of the practice of accounting are theoretically combined with the expansion of the information potential of the existing economic space. The article considers the expansion of the reflection of the scope of the organization in accounting; improving the quality of information and efficiency of accounting, identification and increase in the number of new objects of accounting, development of innovative methods of evaluation of new objects of accounting, formation of approaches to integration of different types of accounting, use of modern information technologies of information collection and processing (blockchain technologies) theoretical, methodological and applied aspects of accounting development.

Keywords: accounting, digitalization, documentation, inventory, valuation, electronic reporting, cost.

Актуальність дослідження. Глобальний розвиток цифрових технологій швидко поширюється на всі сфери життя нашого суспільства. Не залишається осторонь таких змін і бухгалтерський облік, як у теоретичному так і в практичному аспектах. Цифровізація економічних процесів суттєво впливає на процес створення, зберігання та передачу облікової інформації. У зв’язку із цим методологія, інструментарій бухгалтерського обліку не завжди відповідають реаліям, що потребує адаптації до сучасних умов пов'язаних з впровадженням цифрових рішень. В умовах цифровізації, для збереження своєї актуальності бухгалтерський облік повинен позиціонуватися як елемент системи отримання, обробки та передачі економічної інформації. Необхідно чітко представити місце, роль і функцію бухгалтерського обліку в екосистемі. У протилежному випадку його поглинуть сучасні технологічні і мультифункціональні цифрові інформаційні системи, оскільки ці системи динамічно розвиваються і досить агресивно розширюють сферу свого застосування. У звязку із цим важливою $\epsilon$ внутрішня структура бухгалтерського обліку. Необхідно виділення його нових i затребуваних видів. Головними тенденціями цього напряму є: зближення вже існуючих видів обліку, спроби виділити нові, такі як стратегічний, адаптивний, багатоцільовий, креативний, інтелектуальний та ін. Втілення цифрових технологій в облік суттєво впливає на трансформацію облікової методології.

Проблематика адаптації інструментарію бухгалтерського обліку в умовах цифрової модернізації економіки висвітлена у дослідженнях багатьох вітчизняних і зарубіжних науковців, таких як: Шишкова Н. Л. [1], Муравський В. [2], Кулинич М. Б.[3, 7], Приображенська В. В. [4], Варламова Д. В., Алексеева Л. Д. [5], Варданян С. А. [6], та інші. Науковцями досліджено та узагальнено підходи щодо розвитку інструментарію бухгалтерського обліку, проте безперервний процес цифровізації економіки, розвиток IT-технологій вимагає продовження існуючих досліджень у цьому напрямку.

Мета і завдання статті. 3 огляду на вище означене, основною метою роботи є виокремлення ключових орієнтирів змін елементів методу бухгалтерського обліку в контексті цифрової модернізації економіки.

Виклад основного матеріалу та обгрунтування отриманих результатів дослідження.

Цифровізація економіки, розширення інформаційного потенціалу існуючого економічного простору впливає на розвиток теорії і практики ведення бухгалтерського обліку. Інформаційні технології викликають суттєві модифікації як у методології, так і в прикладному напрямку науки про бухгалтерський облік. У звязку 3 цим трансформація бухгалтерського обліку відповідно до нових 
потреб є необхідним етапом у його розвитку. Зміни та поліпшення методології обліку допоможуть не втратити його актуальність в епоху загальної цифровізації. Бухгалтерський облік продукує інформацію, яка стає головним джерелом конкурентоспроможності. Інформація є значимою i являється в рамках організації в формі нематеріального активу. Збираючи певні дані, ми набуваємо знань про досліджуваний обєкт. Звідси випливає, що концепція цифрової економіки полягає не в наданні покупцю готового товару (продукту), а в наборі інструментів, за допомогою яких можна повністю або частково змінити продукт виходячи з запитів споживача. Таким чином, покупець стає виробником, так як безпосередньо бере участь у створенні продукту.

Як зазначає Шишкова Н. Л. збір, опис, зберігання та обробка даних дозволяє отримувати цінну інформацію для використання в управлінні економічними процесами. Але використання цифрового мислення не зосереджено виключно на нових технологіях. Відбувається не просто конвертація даних 3 паперового формату в цифровий, а забезпечується пошук, обробка, синтез звітності, контроль помилок і порівнянності, візуалізація процесів і їх результатів, резервне копіювання за допомогою IT-інструментарію [1]. Це характеризує процес документування господарських операцій у формі електронних носіїв. Муравський В. В. звертає увагу на те, що таким чином успішно реалізується повністю автоматизований збір і реєстрація первинної інформації з використанням технологічних датчиків вимірювання. Процес повністю автоматизованої обробки первинних даних науковець рекомендує розподілити на етапи збору та реєстрації [2]. Збір $є$ фізичним процесом ідентифікації та вимірювання фактів господарської діяльності у формі машинного коду, що не придатний до використання персоналом підприємства. Відповідно зібрані облікові дані не можуть вважатися документами 3 позиції методології обліку. Зібрана облікова інформація передається через комунікаційні канали на реєстрацію, що передбачає іiі оцінку, калькулювання, відображення на рахунках обліку та внесення в єдину базу даних. При опрацюванні бази даних обліковими й управлінськими фахівцям зібрана та зареєстрована інформація може відображатися у формі діалогових вікон, що їх можна визнати електронними документами, або традиційних типових документів за необхідності їхнього подальшого друку. Як підсумок, документування 3 позиції інформатики відбувається після всіх методів обліку разом з формуванням звітних документів для користувачів [2]. Ефективна організація первинного обліку пов'язана в першу чергу з ефективною організацією документообігу. Зважаючи на важливість, документообіг виділяється окремою сферою діяльності підприємства, предметною областю якої є швидкість руху документів. Оптимізація їх руху суттєво підвищує ефективність бізнес-процесів, оскільки прослідковується пряма залежність між ефективністю збереження інформації, можливістю і швидкістю пошуку в базі потрібних даних, сучасним забезпеченням користувачів системи оперативними даними [3]. Однією із переваг цифровізації в частині впливу на організацію документообігу є наявність хмарного середовища для зосередження даних, яке $\epsilon$ безпечним місцем збереження інформації.

Можна погодитися з Приображенською В. В., яка віддає перевагу випереджувальному темпу розвитку бухгалтерського обліку на практиці, а ніж його методології, що прослідковується у застосуванні цифрових технологій форм передачі і збереження інформації [4].

Документально зафіксована інформація потребує перевірки і підтвердження, що втілюється на підприємстві за допомогою інвентаризації. В умовах розвитку цифрових технологій це проводиться 3 використанням програмного забезпечення PI-позначок, що кріпляться до матеріальних цінностей, 3 можливістю радіочастотної безконтактної ідентифікації.

Для організації перманентної інвентаризації рекомендовано обладнати територію підприємства безпровідними сканерами, які здатні визначати місце перебування інвентарного об'єкта. Приміщення підприємства умовно класифіковано за функціональним призначенням на складські, торговельні, виробничі, адміністративні, збутові та інші зони та розроблено порядок обліку переміщення матеріальних запасів. Одночасно рекомендовано відстежувати доступ відповідальних осіб до активів підприємства в момент виявлення правопорушення, що дасть змогу встановлювати винуватих осіб [2].

В умовах розвитку цифрової економіки зазнають значних змін і обєкти обліку. Це пояснюється тим, що зростає кількість показників, що характеризують не тільки економічну сторону бізнесу, а й соціальну, екологічну відповідальність, системність і якість корпоративного управління, наявність нефінансових об 'єктів, таких як: організаційний, людський, інноваційний, репутаційний капітали, 
які забезпечують базу для створення вартості. Сфера обєктів обліку розширюється за рахунок появи нових гібридних і модифікованих форм активів, зобовязань і капіталу: криптовалюти, розумні активи, розумні контракти, інструменти змішаного інвестування, нові форми фінансових угод, електронні потоки коштів, віртуальні монетарні та немонетарні одиниці цінності та ін. Їх відображення в обліку потребує формування нових принципів систематизації та таксономії обєктів обліку, виділення критеріїв визнання, метрик і принципів відображення в економічній інформації.

Тому трансформації підлягає оцінка, як метод обліку в частині застосування багатоваріантних методів оцінки активів і зобов'язань підприємства за різними вимірниками, цінами, валютами для одночасного оперування різнобічною обліковою інформацією.

Достовірно визначити ринкову вартість активів і пасивів підприємства можливо на основі обчислення середньозваженої ціни об'єкта оцінки за методом аналогів продажу, дисконтної вартості, оцінки відновлення чи заміщення через пошук цін у мережі Інтернет. Оцінка (переоцінка) об'єктів 3 відображенням на рахунках бухгалтерського обліку може відбуватися періодично за розробленим алгоритмом після отримання інформації 3 мережі Інтернет про курс іноземних валют, індекс інфляції, обов'язкову норму резервування банками, індекси фондових бірж або вартість аналогічних товарів і послуг на ринку.

Важливу роль в забезпеченні ефективності та результативності діяльності суб'єктів господарювання відіграє облік витрат і калькулювання собівартості продукції (робіт, послуг). Найбільш кардинальних змін в умовах цифровізації обліку зазнає нормативний метод, який трансформується 3 методу калькулювання собівартості в ефективний спосіб автоматизованого управління діяльністю підприємства. 3 метою автоматизованого моніторингу відхилень (фактичної облікової інформації від нормативних показників) Муравський В. В. рекомендує проводити їхню класифікацію за такими напрямками: характером виникнення, структурою, ступенем відображення в обліку, достовірністю, методом розрахунку, залежно від дій працівника, можливістю усунення наслідків, масштабом, впливом на використання ресурсів, належністю до стадії контрольного процесу, одиницями вимірювання, можливістю встановлення винуватих осіб. Автор пропонує порядок впровадження системи комп’ютеризованого нормативного обліку на підприємстві, що охоплює три послідовні етапи: вибір об'єкта нормативного обліку; обгрунтування способу виявлення відхилень (технічних та програмних рішень); розробка керуючого алгоритму реалізації завдань 3 формування системи нормативного обліку для обраного облікового об'єкта 3 метою оптимізації діяльності підприємства [2].

Щодо удосконалення первинної реєстрації господарських операцій, то тут можлива автоматизація облікових записів в умовах застосування нейронних мереж, які аналогічно до людського інтелекту здатні до самонавчання. Первинні облікові дані в нейромережі підлягають автоматизованій кластеризації та розподілу між користувачами відповідно до їхніх інформаційних потреб за наявності багатьох комунікаційних бар'єрів.

На основі первинної облікової інформації ідентифікуються елементи господарської операції, присвоюються номери рахунків обліку, що дає змогу застосувати правило подвійного запису i сформувати обліковий запис. Проте формування облікових проведень без участі облікових фахівців має певні функціональні й організаційні обмеження, пов’язані зі складністю алгоритмізації та автоматизації досвіду, кваліфікації, професійного судження працівників.

Серед експертів в області бухгалтерського обліку висловлюються пропозиції щодо включення в систему рахунків - диференціальних, контрольних рахунків, рахунків для нефінансової інформації, для перспективного обліку. Також розглядається можливість застосування систем, які $\epsilon$ альтернативою подвійному запису. Крім диграфічного і уніграфічного способів запису, існують системи потрійний і четверний записи [5].

В умовах активного розвитку інтернет-сервісів і «хмарних» технологій перспективним визнано розміщення інтегрованої електронної звітності у глобальній мережі з наданням розподіленого доступу до неї. Властива мережі Інтернет технологія гіпертексту дає змогу: значно збільшити інформаційний вміст інтегрованої звітності; забезпечити загальну доступність облікової інформації всім зацікавленим користувачам; зробити звітні документи простими для сприйняття та інтерпретації особами без спеціалізованих знань; спрямувати звітність для виконання державних, 
соціальних, суспільних та екологічних цілей; уніфікувати й гармонізувати звітну інформацію відповідно до національних і міжнародних вимог.

Перспективними видаються ідеї щодо формування єдиного цифрового простору на базі розподіленого доступу до бухгалтерської інформації, що обумовлює залучення в обліковий процес також фахівців в області Blockchain. [4].

Бухгалтерський облік разом з фінансовим аналізом і аудитом $є$ одними з найбільш вдалих сфер впровадження технології блокчейн. Особливості його використання в бухгалтерському обліку відображено в таблиці 1.

Таблиия 1

Особливості викристання технології блокчейн в бухгалтерському обліку

\begin{tabular}{|c|c|c|}
\hline № & найменування & Зміст \\
\hline 1. & 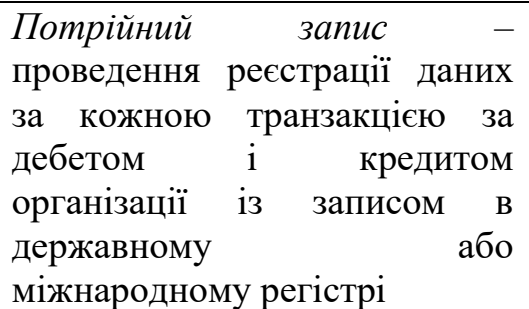 & $\begin{array}{l}\text { Постійний доступ до фінансовой звітності кожної } \\
\text { зареєстрованої організації для регулюючих органів. Це } \\
\text { дозволить продемонструвати фінансову прозорість діяльності } \\
\text { юридичних осіб, постійний контроль, уникнути помилок, } \\
\text { зниження фінансових ризиків, зменшення витрат на } \\
\text { отримання та перевірку документації та ін. }\end{array}$ \\
\hline 2. & Цифровий аудит & $\begin{array}{l}\text { Створення необхідних умов для проведення аудиту на } \\
\text { кожному етапі створення продукції }\end{array}$ \\
\hline 3. & «Розумні» контракти & $\begin{array}{l}\text { Використання електронного підпису дозволить скоротити } \\
\text { часові і трудові витрати на виконання умов договорів. Також } \\
\text { задіяні децентралізація договору, достовірності джерел даних, } \\
\text { довіреності сторін, автоматизація платежів і інше. }\end{array}$ \\
\hline 4. & Хмарне зберігання даних & $\begin{array}{l}\text { Безпечне зберігання всіх даних організації. Економія коштів } \\
\text { на роботу центральних серверів }\end{array}$ \\
\hline 5. & $\begin{array}{l}\text { Спрощення відображення } \\
\text { руху активів всередині } \\
\text { організації }\end{array}$ & $\begin{array}{l}\text { Рух активів здійснюється в формі транзакції, що, в свою чергу, } \\
\text { надає доступ до фінансової і управлінської інформації в } \\
\text { режимі реального часу }\end{array}$ \\
\hline 6. & $\begin{array}{l}\text { Використання транзакцій для } \\
\text { проведення розрахунків } \quad 3 \\
\text { контрагентами організації }\end{array}$ & $\begin{array}{l}\text { Використовувана система блоків в блокчейні дозволить } \\
\text { формувати i списувати дебіторську і кредиторську } \\
\text { заборгованості одночасно, при цьому не потрібно кожного } \\
\text { разу підтверджувати факт транзакції }\end{array}$ \\
\hline 7. & $\begin{array}{l}\text { Спрощення } \quad \text { процесу } \\
\text { управління ресурсами }\end{array}$ & $\begin{array}{l}\text { Завдяки безпечній реєстрації транзакцій спрощується весь } \\
\text { процес управління ресурсами організації }\end{array}$ \\
\hline 8. & $\begin{array}{l}\text { Виключення явищ корупції, } \\
\text { розтрат і непідтверджених } \\
\text { витрат }\end{array}$ & $\begin{array}{l}\text { Вилучення даних негативних факторів стане можливим } \\
\text { завдяки повній прозорості інформації в режимі }\end{array}$ \\
\hline
\end{tabular}

Основними напрямками впровадження блокчейн-технологій в бухгалтерський облік є:

1. Зміна системи бухгалтерського обліку в організаціях. Розробка облікової політики в організаціях різного типу. В науці і практиці на сьогодні виділяють три типи підприємств:

- традиційні організації, які проводять діяльність в звичайному режимі, але при цьому застосовують сучасні технології для вирішення тих чи інших бізнес-завдань;

- організації, які ведуть діяльність і взаємодіють 3 кліентами тільки за допомогою мережі Інтернет та різного роду віртуальних каналів;

- Інтернет-організації, що не привязані до фізичного активу, їх кількість зростає [7].

2. Використання цифрового активу в якості інноваційного об'єкта бухгалтерського обліку. Цифрові активи виступають одним з видів нематеріальних активів, що пов'язано з урахуванням інформації про обєкти, які не мають матеріально-речової форми. Такі активи як франшиза, торгова марка, лояльність клієнтів і інші виступають різновидом нематеріальних активів, i, в тому числі, їх 
можна розглядати як цифрові активи, але при цьому вони часто не є обліковими об'єктами, і крім того, виникає проблема оцінки їх вартості.

\section{Висновки і перпективи подальших досліджень.}

Одним із основних елементів системи бухгалтерського обліку є інформаційна складова двох підсистем - управлінського і фінансового обліку, в яких відбувається переорієнтування з контрольної функції на інформативну, засновану на систематизації питань цифрової трансформації організації. Тому необхідним є створення нових параметрів, методів збору і обробки економічної інформації, а також іiі інтеграції з інформацією про зовнішнє середовище та інших сторін бізнесу.

Удосконалення теорії і формування практики ведення бухгалтерського обліку теоретично об'єднані з розширенням інформаційного потенціалу наявного економічного простору. Ключовими орієнтирами змін елементів методу бухгалтерського обліку в контексті цифрової модернізації економіки є наступні:

• розширення відображення області діяльності організації в обліку;

• підвищення якості інформації та оперативності обліку;

- виявлення і збільшення числа нових об'єктів обліку;

• розробка інноваційних методів оцінки нових об'єктів обліку;

- формування підходів до інтегрування різних видів обліку;

- використання сучасних інформаційних технологій збору і опрацювання інформації (блокчейнтехнологіi);

• розробка теоретичних, методичних і прикладних аспектів розвитку бухгалтерського обліку.

\section{Джерела та література}

1.Шишкова Н. Л. Перспективи IT-модернізації бухгалтерського обліку: актуалізація теорії і практики. Економічний вісник, 2019, №3 https://doi.org/10.33271/ev/67.146

2.Муравський В. В. Компютерно-комунікаційна форма обліку : монографія. Тернопіль : ТНЕУ, 2018. 486 c.

3.Кулинич М. Б. Документування як методичний інструментарій у бухгалтерському обліку: перспективи впровадження електронного документообігу. Економічний часопис Східноєвропейського національного університету імені Лесі Украӥнки : журнал. Луцьк : Вежа-Друк, 2018. № 4(16). С. 148-154

4.Приображенская В. В. Влияние цифровой экономики на развитие компетенций в области бухгалтерского учета. Финансовый журнал. 2019. № 5. C. 50-63. DOI:10.31107/2075-1990-2019-5-50-63 http://oaji.net/articles/2020/8467-1595189921.pdf

5. Варламова Д. В., Алексеева Л. Д., Питання впровадження цифрових технологій в систему бухгалтерського обліку. Вісник Алтайської академії економіки та права. № 52020 248-254

6.Варданян С. А. Базисные векторы развития бухгалтерского учета и аудита на основе блокчейнтехнологии в условиях цифровой экономики. Научное обозрение: теория и практика. 2017. № 11. С. $23-27$.

7.Кулинич М. Б. Цифрова трансформація вітчизняних підприємств в сучасних умовах. Економіка, управління та адміністрування, [S.1.], n. 3(89), p. 8-15, oct. 2019. Доступно за адресою: 〈http://ven.ztu.edu.ua/article/view/180759>. Дата доступу: 04 Nov. 2019 doi:http://dx.doi.org/10.26642/jen-2019$\underline{3}(89)-8-15$

\section{References}

1.Shyshkova N. L. (2019) Perspektyvy IT-modernizatsii bukhhalterskoho obliku: aktualizatsiia teorii i praktyky. [Prospects for IT-modernization of accounting: the actualization of theory and practice]. Ekonomichnyi visnyk. Economic Bulletin , №3 https://doi.org/10.33271/ev/67.146 [in Ukrainian].

2.Muravskyi V. V. (2018) Kompiuterno-komunikatsiina forma obliku : monohrafiia. [Computer-communication form of accounting: monograph]. Ternopil : TNEU, $486 \mathrm{~s}$. [in Ukrainian].

3.Kulynych M. B. (2018) Dokumentuvannia yak metodychnyi instrumentarii u bukhhalterskomu obliku: perspektyvy vprovadzhennia elektronnoho dokumentoobihu. [Documentation as a methodological tool in accounting: prospects for the introduction of electronic document management]. Ekonomichnyi chasopys Skhidnoievropeiskoho natsionalnoho universytetu imeni Lesi Ukrainky. - Economic Journal of Lesya Ukrainka East European National University: Lutsk : Vezha-Druk, № 4(16). S. 148-154 [in Ukrainian].

4.Pryobrazhenskaia V. V. (2019). Vlyianye tsyfrovoi эkonomyky na razvytye kompetentsyi $\mathrm{v}$ oblasty bukhhalterskoho ucheta. [Influence of digital economy on the development of competencies in the field of accounting]. 
Fynansovyj zhurnal. - Financial magazine. № 5. S. 50-63. DOI:10.31107/2075-1990-2019-5-50-63 http://oaji.net/articles/2020/8467-1595189921.pdf [in Ukrainian].

5. Varlamova D. V., Alekseeva L. D., (2020) Pytannia vprovadzhennia tsyfrovykh tekhnolohii v systemu bukhhalterskoho obliku. [The introduction of digital technologies in the accounting system]. Visnyk Altaiskoi akademii ekonomiky ta prava. - Bulletin of the Altai Academy of Economics and Law № 5 c.248-254 [in Russian].

6.Vardanian S. A. (2017) Bazysnыe vektorы razvytyia bukhhalterskoho ucheta y audyta na osnove blokcheintekhnolohyy $\mathrm{v}$ uslovyiakh tsyfrovoi эkonomyky. [Basic vectors of development of accounting and auditing on the basis of blockchain technology in the digital economy]. Nauchnoe obozrenye: teoryia y praktyka. - Scientific review: theory and practice. № 11. S. 23-27. [in Russian].

7.Kulynych M. B. (2019) Tsyfrova transformatsiia vitchyznianykh pidpryiemstv v suchasnykh umovakh. [Digital transformation of domestic enterprises in modern conditions]. Ekonomika, upravlinnia ta administruvannia. Economics, Management, and Administration [S.1.], n. 3(89), p. 8-15, Dostupno za adresoiu: <http://ven.ztu.edu.ua/article/view/180759>. doi:http://dx.doi.org/10.26642/jen-2019-3 (89)-8-15 [in Ukrainian].

Стаття надійшла до редакції 20.11.2020 p 